\title{
Optimal fermentation conditions for maximizing the ethanol production by Kluyveromyces fragilis from cheese whey powder
}

\author{
Giuliano Dragone $^{a, *}$, Solange I. Mussatto ${ }^{a}$, João B. Almeida e Silva ${ }^{b}$, José A. Teixeira ${ }^{a}$ \\ ${ }^{\mathrm{a}}$ IBB - Institute for Biotechnology and Bioengineering, Centre of Biological Engineering, University of Minho, Campus de Gualtar, \\ 4710-057 Braga, Portugal \\ ${ }^{\mathrm{b}}$ Department of Biotechnology, Engineering College of Lorena, University of São Paulo, Estrada Municipal do Campinho s/n, \\ 12602-810 Lorena/SP, Brazil
}

\section{A R T I C L E I N F O}

Article history:

Received 7 October 2009

Received in revised form

23 January 2011

Accepted 25 January 2011

Available online 17 February 2011

Keywords:

Biofuels

Cheese whey

Ethanol

Fermentation

Kluyveromyces fragilis

Lactose

\begin{abstract}
A B S T R A C T
Cheese whey powder (CWP) is an attractive raw material for ethanol production since it is a dried and concentrated form of $\mathrm{CW}$ and contains lactose in addition to nitrogen, phosphate and other essential nutrients. In the present work, deproteinized CWP was utilized as fermentation medium for ethanol production by Kluyveromyces fragilis. The individual and combined effects of initial lactose concentration (50-150 $\mathrm{kg} \mathrm{m}^{-3}$ ), temperature $\left(25-35^{\circ} \mathrm{C}\right)$ and inoculum concentration $\left(1-3 \mathrm{~kg} \mathrm{~m}^{-3}\right)$ were investigated through a $2^{3}$ fullfactorial central composite design, and the optimal conditions for maximizing the ethanol production were determined. According to the statistical analysis, in the studied range of values, only the initial lactose concentration had a significant effect on ethanol production, resulting in higher product formation as the initial substrate concentration was increased. Assays with initial lactose concentration varying from 150 to $250 \mathrm{~kg} \mathrm{~m}^{-3}$ were thus performed and revealed that the use of $200 \mathrm{~kg} \mathrm{~m}^{-3}$ initial lactose concentration, inoculum concentration of $1 \mathrm{~kg} \mathrm{~m}^{-3}$ and temperature of $35^{\circ} \mathrm{C}$ were the best conditions for maximizing the ethanol production from CWP solution. Under these conditions, $80.95 \mathrm{~kg} \mathrm{~m}^{-3}$ of ethanol was obtained after $44 \mathrm{~h}$ of fermentation.
\end{abstract}

(c) 2011 Elsevier Ltd. All rights reserved.

\section{Introduction}

The dairy industry represents an important part of the food processing industry and contributes significant liquid process residues that can be used for the production of ethanol [1]. Cheese whey (CW), a by-product of the cheese manufacturing process whose major components are lactose $\left(45-50 \mathrm{~kg} \mathrm{~m}^{-3}\right)$, proteins $\left(6-8 \mathrm{~kg} \mathrm{~m}^{-3}\right)$, lipids $\left(4-5 \mathrm{~kg} \mathrm{~m}^{-3}\right)$, and mineral salts (8-10\% of dried extract), constitutes an inexpensive and nutritionally rich raw material for the production of different compounds [2,3]. Ethanol production by bioconversion of whey is an alternative of great interest for reuse of this industrial by-product [4]. In addition, the development of ethanol production methods is stimulated by the possibility of using ethanol as a component in biofuels [5,6]. However, the production of ethanol from non-concentrated CW is not economically feasible because the levels of ethanol obtained at the end of fermentation reach only about $20-30 \mathrm{dm}^{3} \mathrm{~m}^{-3}$. Distillation costs for ethanol separation from dilute fermentation broths $\left(20-30 \mathrm{dm}^{3} \mathrm{~m}^{-3} \mathrm{EtOH}\right)$ is a major cost item in ethanol fermentation of CW [2]. Ultrafiltration (UF) processes have been used to concentrate lactose in $\mathrm{CW}$ before

\footnotetext{
* Corresponding author. Tel.: +351 253604 424; fax: +351 253604429.

E-mail address: gdragone@deb.uminho.pt (G. Dragone). 
fermentation [7]. UF improves the lactose concentration by a factor of 5-6, but is expensive (approx. $50 \$ \mathrm{~m}^{-3}$ original dilute CW) [8].

Dry cheese whey powder (CWP) may be an attractive raw material for ethanol production. CWP is a dried and concentrated form of CW and contains lactose in addition to nitrogen, phosphate and other essential nutrients [9]. Utilization of CWP instead of CW for ethanol fermentations has significant advantages such as elimination of costly ultrafiltration processes to concentrate lactose before fermentation, compact volume, longterm stability and high concentrations of lactose and other nutrients yielding high ethanol concentrations by fermentation. Moreover, the cost of CWP production from CW by spray or drum drying varies between 0.2 and $0.4 \$$ per $\mathrm{kg}$ CWP $\left(10-20 \$ \mathrm{~m}^{-3}\right.$ original dilute $\mathrm{CW}$ ), which is much lower than distillation costs for pure ethanol production from dilute CW $[8,10]$.

It is known that the fermentation process performance is affected by operational conditions such as temperature, stirring rate, initial inoculum and substrate concentrations, dissolved oxygen, among others. A suitable control of these variables is of great importance for a good process performance and obtainment of high-quality products. The present study aimed to optimize the conditions for ethanol production from CWP through RSM designed with central composite design. Three factors were selected as process (independent) variables: initial lactose concentration, temperature and inoculum concentration; while the ethanol concentration, substrate consumption and fermentative parameters (ethanol yield factor, $\mathrm{Y}_{\mathrm{P} / \mathrm{S}}$; ethanol volumetric productivity, $\mathrm{Q}_{\mathrm{P}}$; ethanol yield per cell, $\mathrm{Y}_{\mathrm{P} / \mathrm{x}}$; and bioconversion efficiency, $\eta$ ) were selected as responses (dependent) variables.

\section{Materials and methods}

\subsection{Microorganism and inoculum preparation}

Kluyveromyces fragilis (Kf1) from the culture collection of the Centre of Biological Engineering, University of Minho (Portugal), was the yeast strain employed in the experiments. This strain was supplied by University of Lavras (Department of Biology), Brazil, and was isolated from cocoa fermentation. Cells of this yeast were maintained at $4^{\circ} \mathrm{C}$ on YPD agar plates. The inoculum was prepared by transferring a loopful of cells from a freshly grown culture (incubated at $30^{\circ} \mathrm{C}$ for $30 \mathrm{~h}$ ) to $500 \mathrm{ml}$ Erlenmeyer flasks containing $100 \mathrm{ml}$ sterile CWP solution $\left(50 \mathrm{~kg} \mathrm{~m}^{-3}\right.$ lactose). The flasks were incubated on a rotary shaker at $3.3 \mathrm{~Hz}$, $30{ }^{\circ} \mathrm{C}$ for $24 \mathrm{~h}$. After this time, the cells were recovered by centrifugation (4200 g, $15 \mathrm{~min}$ ), washed with sterilized distilled water, and directly resuspended in the fermentation medium.

\subsection{Medium and fermentation conditions}

Cheese whey powder (CWP) was kindly supplied by Lactogal (Porto, Portugal). CWP composition (sample of January, 2008) included $\left(\mathrm{w} \mathrm{w}^{-1}\right)$ : $>73 \%$ lactose, $12 \%$ proteins, $1.5 \%$ lipids and $<5 \%$ moisture. To be used as fermentation medium, CWP solutions with different initial lactose concentrations were prepared, $\mathrm{pH}$-adjusted to 5 by addition of $1 \mathrm{kmol} \mathrm{m}^{-3}$ citric acid, and deproteinized by heat treatment at $115^{\circ} \mathrm{C}$ for $15 \mathrm{~min}$.
The precipitates were removed by centrifugation at $5600 \mathrm{~g}$ and $10^{\circ} \mathrm{C}$ for $15 \mathrm{~min}$, and the supernatants were used as fermentation medium.

Batch fermentations were performed in $500 \mathrm{ml}$ Erlenmeyer flasks containing $100 \mathrm{ml}$ of medium. Flasks were maintained in an orbital shaker at $2.5 \mathrm{~Hz}$ for $44 \mathrm{~h}$. Different values of initial lactose concentration, temperature and inoculum concentration were used in the experiments (Table 1 ).

In the second step, the assays for determination of the best initial lactose concentration (varying from 150 to $250 \mathrm{~kg} \mathrm{~m}^{-3}$ ) were also performed in Erlenmeyer flasks as above described. However, in this case the temperature and initial inoculum concentration were fixed at $35^{\circ} \mathrm{C}$ and $1 \mathrm{~kg} \mathrm{~m}^{-3}$, respectively.

The fermentation runs were monitored through periodic sampling in order to determine the cell growth, lactose consumption and ethanol production. All the experiments were performed in duplicate and mean values are given. The kinetic parameters of fermentations were calculated at the end of the runs. The ethanol yield factor $\left(\mathrm{Y}_{\mathrm{P} / \mathrm{S}}, \mathrm{kg} \mathrm{kg}^{-1}\right)$ was defined as the ratio between the ethanol concentration $\left(\mathrm{kg} \mathrm{m}^{-3}\right)$ and lactose consumed $\left(\mathrm{kg} \mathrm{m}^{-3}\right)$. The ethanol yield per cell $\left(\mathrm{Y}_{\mathrm{P} / \mathrm{x}}, \mathrm{kg} \mathrm{kg}^{-1}\right)$ was defined as the ratio between ethanol and total cell concentrations $\left(\mathrm{kg} \mathrm{m}^{-3}\right)$. The ethanol productivity $\left(\mathrm{Q}_{\mathrm{p}}, \mathrm{kg} \mathrm{m}^{-3} \mathrm{~h}^{-1}\right)$ was defined as the ratio between ethanol concentration $\left(\mathrm{kg} \mathrm{m}^{-3}\right)$ and fermentation time $(\mathrm{h})$. The efficiency of ethanol production $(\eta, \%)$ was defined as the ratio between the ethanol concentration $\left(\mathrm{kg} \mathrm{m}^{-3}\right)$ and the maximum theoretical ethanol concentration $\left(\mathrm{kg} \mathrm{m}^{-3}\right)$ that could be achieved considering the theoretical value of $0.538 \mathrm{~kg}$ ethanol per $\mathrm{kg}$ consumed lactose [11].

\subsection{Analytical methods}

The fermented media samples were centrifuged at $2700 \mathrm{~g}$ for $10 \mathrm{~min}$ and the supernatant was used for lactose and ethanol quantification. The remaining solid was washed with distilled water, centrifuged and then, diluted with distilled water for analysis of biomass. The cell concentration was determined in a spectrophotometer at $600 \mathrm{~nm}$, by means of a calibration curve (biomass dry weight vs. optical density (OD)) previously obtained. Samples were diluted to give an absorbance in the range of $0.05-0.7$.

The lactose and ethanol concentrations in the supernatant were determined by high-performance liquid chromatography, in a Jasco chromatograph equipped with a refractive index (RI) detector (Jasco 830-RI) and a Chrompack $(300 \times 6.5 \mathrm{~mm})$ column at $60^{\circ} \mathrm{C}$, using $5 \mathrm{mM}$ sulfuric acid as the eluent at a flow rate of $0.5 \mathrm{ml} \mathrm{min}{ }^{-1}$ and a sample volume of $20 \mu \mathrm{l}$.

Table 1 - Experimental ranges and levels of the independent process variables according to the $2^{3}$ full-factorial central composite design.

\begin{tabular}{lcrrr} 
Independent variable & Symbol & \multicolumn{3}{c}{ Range and levels } \\
\cline { 2 - 5 } & & -1 & 0 & +1 \\
\hline $\begin{array}{l}\text { Initial lactose concentration } \\
\left(\mathrm{kg} \mathrm{m}^{-3}\right)\end{array}$ & $\mathrm{X}_{1}$ & 50 & 100 & 150 \\
$\begin{array}{l}\text { Temperature }\left({ }^{\circ} \mathrm{C}\right) \\
\begin{array}{l}\text { Inoculum concentration } \\
\left(\mathrm{kg} \mathrm{m}^{-3}\right)\end{array}\end{array}$ & $\mathrm{X}_{2}$ & 25 & 30 & 35 \\
\hline
\end{tabular}




\subsection{Experimental design and optimization by response surface methodology}

A $2^{3}$ full-factorial central composite design with three coded levels, leading to 17 sets of experiments was made to establish the effects of the variables (initial lactose concentration, temperature, and inoculum concentration) on ethanol production from CWP solution. For statistical analysis, the independent variables were coded according to the Eq. (1), where each independent variable is represented by $x_{i}$ (coded value), $X_{i}$ (real value), $X_{0}$ (real value at the center point), and $\Delta X_{i}$ (step change value). The range and the levels of the variables are given in Table 1 . The ethanol concentration, substrate consumption, ethanol yield factor, ethanol volumetric productivity, ethanol yield per cell, and bioconversion efficiency were taken as dependent variables or responses of the experimental design.

$x_{i}=\left(X_{i}-X_{0}\right) / \Delta X_{i}$

The experimental results were fitted with a second-order polynomial equation by multiple regression analysis. The quadratic mode for predicting the optimal point was expressed according to eq. (2), where $\widehat{y}_{i}$ represents the response variable, $b_{0}$ is the interception coefficient, $b_{i}, b_{i i}$ and $b_{i j}$ are the regression coefficients, $n$ is the number of studied variables, and $X_{i}$ and $X_{j}$ represent the independent variables. Where possible, the model was simplified by elimination of statistically insignificant terms.

$\widehat{y}_{i}=b_{0}+\sum_{i=1}^{n} b_{i} X_{i}+\sum_{i=1}^{n} b_{i i} X_{i}^{2}+\sum_{i=1}^{n-1} \sum_{j=i+1}^{n} b_{i j} X_{i} X_{j}$

The quality of the fitted polynomial model was expressed by the coefficient of determination $\mathrm{R}^{2}$, and its statistical significance was checked by the F-test. The significance of the regression coefficients was tested by t-value. Results were analyzed by the Experimental Design Module of the Statistica 5.0 software (Statsoft, USA). The model permitted evaluation of the effects of linear, quadratic and interactive terms of the independent variables on the chosen dependent variables.

\section{Results and discussion}

The yeast strain used in the present work was a $\mathrm{K}$. fragilis selected among 8 Kluyveromyces strains (unpublished results). The experimental results obtained by cultivation of this yeast in deproteinized CWP solution, under different operational conditions according to a $2^{3}$ central composite design, are shown in Table 2. It can be noted that $K$. fragilis was able to growth and produce ethanol under all the evaluated fermentation conditions, however, the production strongly varied according to the levels employed for the independent variables. The highest ethanol concentration $\left(55.9 \mathrm{~kg} \mathrm{~m}^{-3}\right)$ was obtained when using an initial lactose concentration of $150 \mathrm{~kg} \mathrm{~m}{ }^{-3}, 30{ }^{\circ} \mathrm{C}$, and $2 \mathrm{~kg} \mathrm{~m}^{-3}$ inoculum concentration (conditions of run 10). Under these same conditions, the ethanol yield factor and volumetric productivity also achieved the highest values $\left(\mathrm{Y}_{\mathrm{P} / \mathrm{S}}=0.37 \mathrm{~kg} \mathrm{~kg}^{-1} ; \mathrm{Q}_{\mathrm{P}}=1.27 \mathrm{~kg} \mathrm{~m}^{-3} \mathrm{~h}^{-1}\right)$.

Due to the large difference observed in the ethanol production, a statistical analysis was carried out to identify the variables that had the greatest influence on this bioconversion process. Table 3 shows the Student's t-test and $p$-values used to determine the statistical significance of the independent variables (initial lactose concentration, temperature, and inoculum concentration) on the response variables (ethanol concentration, $\mathrm{Y}_{\mathrm{P} / \mathrm{S}}, \mathrm{Q}_{\mathrm{P}}, \eta, \mathrm{Y}_{\mathrm{P} / \mathrm{x}}$, and substrate consumption). According to this analysis the initial lactose concentration was the variable that affected all the analyzed responses. In addition, it was the unique variable with

Table 2 - Experimental matrix and results of ethanol concentration (Et), ethanol per biomass yield factor $\left(Y_{\mathrm{P} / \mathrm{x}}\right)$, and ethanol yield factor $\left(\mathrm{Y}_{\mathrm{P} / \mathrm{S}}\right)$, with coded levels of the variables according to a $2^{3}$ full-factorial central composite design.

\begin{tabular}{|c|c|c|c|c|c|c|c|c|c|c|}
\hline \multirow[t]{2}{*}{ Runs } & \multicolumn{3}{|c|}{ Independent variables $^{a}$} & \multicolumn{7}{|c|}{ Responses } \\
\hline & $\mathrm{X}_{1}$ & $\mathrm{X}_{2}$ & $\mathrm{X}_{3}$ & $\begin{array}{c}\text { Cell } \\
\left(\mathrm{kg} \mathrm{m}^{-3}\right)\end{array}$ & $\begin{array}{l}\text { S cons. } \\
(\%)\end{array}$ & $\begin{array}{c}\mathrm{Et} \\
\left(\mathrm{kg} \mathrm{m}^{-3}\right)\end{array}$ & $\begin{array}{c}\mathrm{Y}_{\mathrm{P} / \mathrm{x}} \\
\left(\mathrm{kg} \mathrm{kg}^{-1}\right)\end{array}$ & $\begin{array}{c}\mathrm{Y}_{\mathrm{P} / \mathrm{S}} \\
\left(\mathrm{kg} \mathrm{kg}^{-1}\right)\end{array}$ & $\left(\mathrm{kg} \mathrm{m}^{-3} \mathrm{~h}^{-1}\right)$ & $\begin{array}{c}\eta \\
(\%)\end{array}$ \\
\hline 1 & -1 & -1 & -1 & 4.9 & 100 & 12.7 & 2.59 & 0.25 & 0.29 & 45.67 \\
\hline 2 & -1 & -1 & +1 & 6.8 & 100 & 13.4 & 1.97 & 0.26 & 0.30 & 48.83 \\
\hline 3 & -1 & +1 & -1 & 5.5 & 100 & 12.0 & 2.18 & 0.27 & 0.27 & 54.86 \\
\hline 4 & -1 & +1 & +1 & 7.2 & 100 & 13.4 & 1.86 & 0.35 & 0.30 & 66.07 \\
\hline 5 & +1 & -1 & -1 & 7.4 & 94.6 & 48.2 & 6.51 & 0.34 & 1.10 & 60.13 \\
\hline 6 & +1 & -1 & +1 & 9.1 & 95.3 & 47.0 & 5.16 & 0.36 & 1.07 & 64.29 \\
\hline 7 & +1 & +1 & -1 & 7.4 & 100 & 48.5 & 6.55 & 0.35 & 1.10 & 64.76 \\
\hline 8 & +1 & +1 & +1 & 7.5 & 100 & 41.5 & 5.53 & 0.28 & 0.94 & 52.44 \\
\hline 9 & -1 & 0 & 0 & 6.6 & 100 & 10.3 & 1.56 & 0.22 & 0.23 & 40.65 \\
\hline 10 & +1 & 0 & 0 & 8.7 & 100 & 55.9 & 6.43 & 0.37 & 1.27 & 69.04 \\
\hline 11 & 0 & -1 & 0 & 7.8 & 100 & 28.8 & 3.69 & 0.33 & 0.66 & 62.03 \\
\hline 12 & 0 & +1 & 0 & 7.3 & 100 & 24.5 & 3.36 & 0.28 & 0.56 & 51.81 \\
\hline 13 & 0 & 0 & -1 & 7.5 & 100 & 32.4 & 4.32 & 0.33 & 0.74 & 60.58 \\
\hline 14 & 0 & 0 & +1 & 9.0 & 100 & 28.8 & 3.20 & 0.29 & 0.66 & 53.26 \\
\hline 15 & 0 & 0 & 0 & 8.4 & 100 & 26.1 & 3.11 & 0.30 & 0.59 & 55.64 \\
\hline 16 & 0 & 0 & 0 & 8.3 & 100 & 25.6 & 3.08 & 0.30 & 0.58 & 55.00 \\
\hline 17 & 0 & 0 & 0 & 8.3 & 100 & 23.8 & 2.87 & 0.29 & 0.54 & 53.88 \\
\hline
\end{tabular}

a $\mathrm{X}_{1}=$ coded values of lactose; $\mathrm{X}_{2}=$ coded values of temperature; $\mathrm{X}_{3}=$ coded values of inoculum concentration. 
Table 3 - Effect estimates, standard errors and ethanol concentration (Et), substrate consumption (Sc), bioconversion efficiency $(\eta)$, ethanol yield per cell $\left(Y_{\mathrm{P} / \mathrm{x}}\right)$, ethanol yield factor $\left(\mathrm{Y}_{\mathrm{P} / \mathrm{S}}\right)$, and ethanol volumetric productivity $\left(Q_{\mathrm{P}}\right)$ during the bioconversion of cheese whey power solution by Kluyveromyces fragilis, according to the $2^{3}$ full-factorial central composite design.

\begin{tabular}{|c|c|c|c|c|c|c|c|c|c|}
\hline & $\begin{array}{c}\text { Estimated } \\
\text { effects }\end{array}$ & $\begin{array}{c}\text { Standard } \\
\text { errors }\end{array}$ & $t_{\text {value }}$ & $\begin{array}{c}\text { Estimated } \\
\text { effects }\end{array}$ & $\begin{array}{c}\text { Standard } \\
\text { errors }\end{array}$ & $t_{\text {value }}$ & $\begin{array}{c}\text { Estimated } \\
\text { effects }\end{array}$ & $\begin{array}{c}\text { Standard } \\
\text { errors }\end{array}$ & $\mathrm{t}_{\text {value }}$ \\
\hline Variables and interactions & & $\mathrm{Et}$ & & & Sc & & & $\eta$ & \\
\hline $\mathrm{X}_{1}$ & 35.860 & \pm 2.498 & $14.357^{\mathrm{a}}$ & -2.016 & \pm 0.570 & $-3.538^{\mathrm{a}}$ & 10.916 & \pm 4.724 & $2.310^{\mathrm{b}}$ \\
\hline $\mathrm{X}_{1}^{2}$ & 7.641 & \pm 4.826 & 1.583 & -0.994 & \pm 1.101 & -0.903 & -1.468 & \pm 9.127 & -0.161 \\
\hline $\mathrm{X}_{2}$ & -2.040 & \pm 2.498 & -0.817 & 2.016 & \pm 0.570 & $3.538^{\mathrm{a}}$ & 1.798 & \pm 4.724 & 0.381 \\
\hline $\mathrm{X}_{2}^{2}$ & -5.259 & \pm 4.826 & -1.090 & -0.994 & \pm 1.101 & -0.903 & 2.682 & \pm 9.127 & 0.294 \\
\hline $\mathrm{X}_{3}$ & -1.940 & \pm 2.498 & -0.777 & 0.132 & \pm 0.570 & 0.232 & -0.222 & \pm 4.724 & -0.047 \\
\hline $\mathrm{X}_{3}^{2}$ & 2.641 & \pm 4.826 & 0.547 & -0.994 & \pm 1.101 & -0.903 & 2.682 & \pm 9.127 & 0.294 \\
\hline $\mathrm{X}_{1} \mathrm{X}_{2}$ & -1.125 & \pm 2.793 & -0.403 & 2.520 & \pm 0.637 & $3.956^{\mathrm{a}}$ & -8.413 & \pm 5.282 & -1.593 \\
\hline $\mathrm{X}_{1} \mathrm{X}_{3}$ & -2.575 & \pm 2.793 & -0.922 & 0.165 & \pm 0.637 & 0.259 & -5.633 & \pm 5.282 & -1.066 \\
\hline $\mathrm{X}_{2} \mathrm{X}_{3}$ & -1.275 & \pm 2.793 & -0.457 & -0.165 & \pm 0.637 & -0.259 & -2.108 & \pm 5.282 & -0.399 \\
\hline Variables and interactions & & $\mathrm{Y}_{\mathrm{P} / \mathrm{x}}$ & & & $\mathrm{Y}_{\mathrm{P} / \mathrm{S}}$ & & & $\mathrm{Q}_{\mathrm{P}}$ & \\
\hline $\mathrm{X}_{1}$ & 4.004 & \pm 0.246 & $16.288^{\mathrm{a}}$ & 0.070 & \pm 0.024 & $2.968^{\mathrm{b}}$ & 0.818 & \pm 0.058 & $14.182^{\mathrm{a}}$ \\
\hline $\mathrm{X}_{1}^{2}$ & 1.006 & \pm 0.475 & 2.119 & -0.011 & \pm 0.046 & -0.232 & 0.164 & \pm 0.111 & 1.470 \\
\hline $\mathrm{X}_{2}$ & -0.088 & \pm 0.246 & -0.358 & -0.002 & \pm 0.024 & -0.085 & -0.050 & \pm 0.058 & -0.867 \\
\hline $\mathrm{X}_{2}^{2}$ & 0.066 & \pm 0.475 & 0.140 & 0.009 & \pm 0.046 & 0.207 & -0.116 & \pm 0.111 & -1.043 \\
\hline $\mathrm{X}_{3}$ & -0.886 & \pm 0.246 & $-3.604^{a}$ & 0.000 & \pm 0.024 & 0.000 & -0.046 & \pm 0.058 & -0.798 \\
\hline $\mathrm{X}_{3}^{2}$ & 0.536 & \pm 0.475 & 1.130 & 0.019 & \pm 0.046 & 0.427 & 0.064 & \pm 0.111 & 0.573 \\
\hline $\mathrm{X}_{1} \mathrm{X}_{2}$ & 0.233 & \pm 0.275 & 0.846 & -0.045 & \pm 0.026 & -1.707 & -0.028 & \pm 0.064 & -0.426 \\
\hline $\mathrm{X}_{1} \mathrm{X}_{3}$ & -0.358 & \pm 0.275 & -1.301 & -0.035 & \pm 0.026 & -1.327 & -0.058 & \pm 0.064 & -0.892 \\
\hline $\mathrm{X}_{2} \mathrm{X}_{3}$ & 0.158 & \pm 0.275 & 0.573 & -0.005 & \pm 0.026 & -0.190 & -0.028 & \pm 0.064 & -0.426 \\
\hline
\end{tabular}

significant influence on ethanol production, $\mathrm{Y}_{\mathrm{P} / \mathrm{S}}, \mathrm{Q}_{\mathrm{P}}$, and $\eta$ values. For all of these responses, only the linear effect of the initial lactose concentration was significant at $95 \%$ confidence level. Such effect had a positive signal, indicating that the ethanol concentration, $\mathrm{Y}_{\mathrm{P} / \mathrm{S}}, \mathrm{Q}_{\mathrm{P}}$, and $\eta$ values increased by increasing the initial lactose concentration. Temperature and inoculum concentration did not present main significant effect for these responses, suggesting that temperature between 25 and $35{ }^{\circ} \mathrm{C}$ and inoculum concentration varying from 1 to $3 \mathrm{~kg} \mathrm{~m}^{-3}$ did not affect the $\mathrm{Y}_{\mathrm{P} / \mathrm{S}}, \mathrm{Q}_{\mathrm{P}}, \eta$, and ethanol production by $\mathrm{K}$. fragilis from CWP solution. Interaction effects among the studied variables were also not significant at $95 \%$ confidence level.

The ethanol yield per cell $\left(\mathrm{Y}_{\mathrm{P} / \mathrm{x}}\right)$ was also mainly affected by the initial lactose concentration, resulting in higher ethanol production by cell as the initial substrate concentration was increased (positive effect) (Table 3). Moreover, the inoculum concentration had also a significant effect at $95 \%$ confidence level, which had a negative signal, indicating that the lower the inoculum concentration, the higher the ethanol amount produced by cell. In addition, the statistical analysis carried out for substrate consumption revealed that the inoculum variation from 1 to $3 \mathrm{~kg} \mathrm{~m}^{-3}$ did not have influence in the lactose consumption by yeast. Inoculum variation from 1 to $3 \mathrm{~kg} \mathrm{~m}^{-3}$ was also not significant for ethanol production. By considering these facts it can be concluded that when using $1 \mathrm{~kg} \mathrm{~m}^{-3}$ inoculum, the cells were able to consume the same lactose amount and produce the same final ethanol concentration that when using $3 \mathrm{~kg} \mathrm{~m}^{-3}$ inoculum. Consequently, the product formation by cell was higher. As can be seen in Table 3 , when the inoculum concentration was decreased from 3 to
$1 \mathrm{~kg} \mathrm{~m}^{-3}$, an average increase of $3.604 \mathrm{~kg} \mathrm{~kg}^{-1}$ was observed in $\mathrm{Y}_{\mathrm{P} / \mathrm{x}}$.

Regarding the substrate consumption, although the lactose was completely consumed in almost all the fermentations, the statistical analysis pointed out that this response was influenced by the initial lactose concentration and temperature (Table 3). The initial lactose concentration had a main and negative effect, indicating that the substrate consumption increased as the initial substrate concentration used in the experiments decreased. On the other hand, the temperature had a main and positive effect, revealing that the temperature increase favored the substrate consumption by the microorganism. Increasing the fermentation temperature from $23^{\circ} \mathrm{C}$ to $42{ }^{\circ} \mathrm{C}$ also enhanced the lactose utilization by Lactobacillus helveticus [12]. According to the authors, the rate of reaction for microorganisms really increases with increasing temperature, until a limiting maximum value is reached.

After identification of the main variables affecting the ethanol production, a multiple regression analysis was performed to fit the experimental data to polynomial equations, obtaining the coefficients given in Table 4 . The models were simplified by elimination of statistically insignificant terms. The quality of the fitted polynomial models was expressed by the coefficient of determination $\mathrm{R}^{2}$. As can be observed, models explaining more than $90 \%$ of the variations observed in the responses $\left(R^{2}>0.9\right)$ could be adjusted for the responses ethanol concentration, $Q_{P}$, and $\mathrm{Y}_{\mathrm{P} / \mathrm{x}}$. The high $\mathrm{R}^{2}$ values mean that the models accurately represent the data in the experimental region studied, explaining more than $90 \%$ of the variability in the responses.

The relation between variables and ethanol concentration can be best visualized by examining the surface plots given in 
Table 4 - Model equations for the response surfaces fitted to the experimental data points, and the respective $\mathbf{R}^{2}$.

\begin{tabular}{|c|c|c|}
\hline Response & Model equations & $\mathrm{R}^{2}$ \\
\hline $\begin{array}{l}\text { Ethanol concentration } \\
\qquad\left(\mathrm{Et} \text {, in } \mathrm{kg} \mathrm{m}^{-3}\right)\end{array}$ & $E t=28.99+17.93 \mathrm{X}_{1}$ & 0.94 \\
\hline $\begin{array}{l}\text { Ethanol volumetric productivity } \\
\qquad\left(\mathrm{Q}_{\mathrm{p}} \text {, in } \mathrm{kg} \mathrm{m}^{-3} \mathrm{~h}^{-1}\right)\end{array}$ & $Q_{P}=0.659+0.409 X_{1}$ & 0.94 \\
\hline $\begin{array}{l}\text { Ethanol yield by cell } \\
\left(\mathrm{Y}_{\mathrm{P} / \mathrm{x}}, \text { in } \mathrm{kg} \mathrm{kg}^{-1}\right)\end{array}$ & $\begin{aligned} \mathrm{Y}_{\mathrm{P} / \mathrm{x}}= & 3.376+2.002 \mathrm{X}_{1} \\
& +0.658 \mathrm{X}_{1}^{2}-0.443 \mathrm{X}_{3}\end{aligned}$ & 0.96 \\
\hline
\end{tabular}

Fig. 1, which were plotted as a function of two variables at a time and holding the other variable at a fixed level. Fig. 1 clearly shows that increasing initial lactose concentration resulted in higher ethanol production, with maxima values $\left(\geq 41.5 \mathrm{~kg} \mathrm{~m}^{-3}\right)$ being achieved under the maximum tested concentration $\left(150 \mathrm{~kg} \mathrm{~m}^{-3}\right)$. Similar plot surfaces were
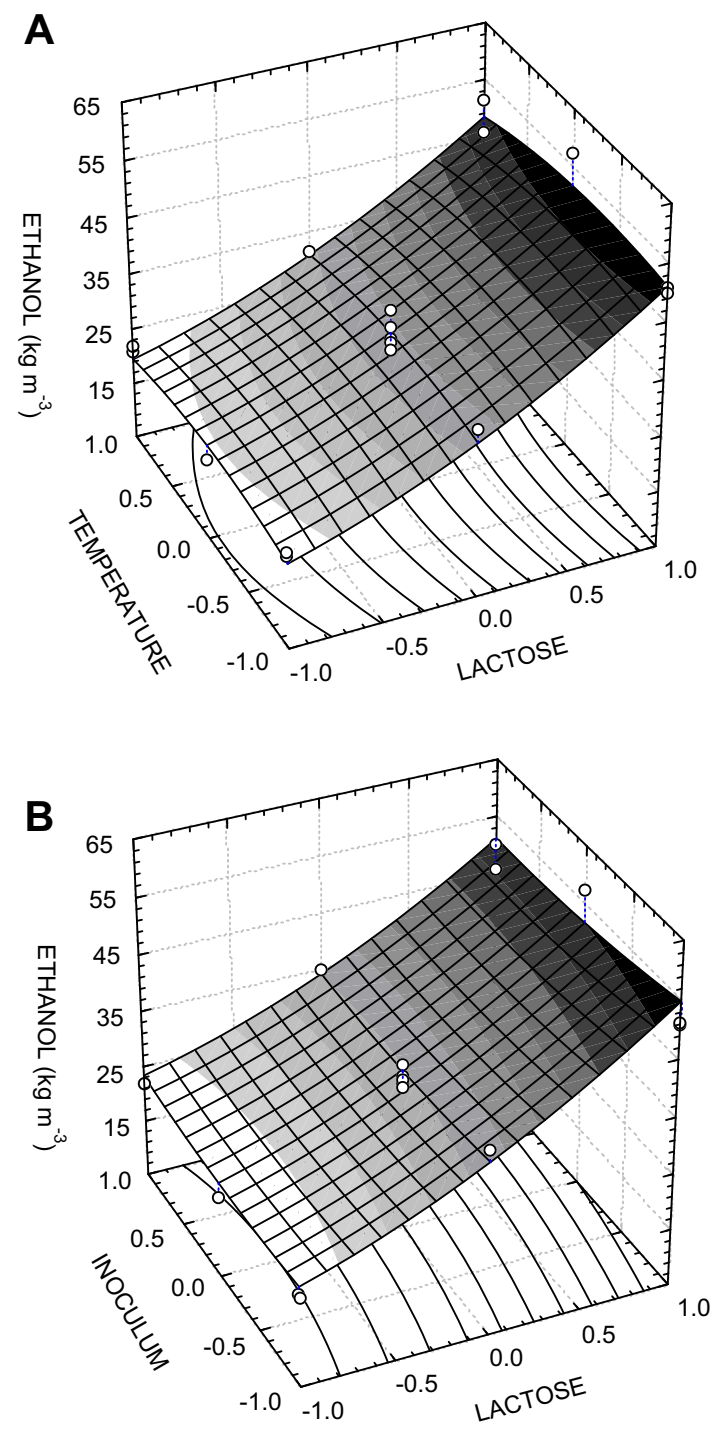

Fig. 1 - Response surface of ethanol production from cheese whey powder by $\mathrm{K}$. fragilis as a function of: (A) initial lactose concentration and temperature, (B) initial lactose and inoculum concentrations. obtained for the $\mathrm{Q}_{\mathrm{P}}$ response (not shown). A comparable behavior was also verified for Kluyveromyces marxianus DSMZ7239 yeast using initial lactose concentrations up to $75 \mathrm{~kg} \mathrm{~m}^{-3}$ [13]. However, maxima ethanol amounts produced in the present study were higher than those obtained by direct fermentation of crude (non-concentrated) cheese whey [14] or cheese whey powder [13].

Based on the statistical analysis results, assays were performed in a following step to evaluate the possibility of increasing the ethanol concentration by increasing the initial lactose concentration to values above $150 \mathrm{~kg} \mathrm{~m}^{-3}$ (up to $250 \mathrm{~kg} \mathrm{~m}^{-3}$ ). The values of temperature and inoculum used in these experiments were fixed at $35^{\circ} \mathrm{C}$ and $1 \mathrm{~kg} \mathrm{~m}^{-3}$, respectively. This temperature was chosen because the solubility of lactose solutions increase with the temperature increase and this is important as higher the concentration of the cheese whey solution used. On the other hand, the inoculum concentration was fixed at $1 \mathrm{~kg} \mathrm{~m}^{-3}$ due to economical and practical reasons.

Fig. 2 shows the experimental results obtained in these experiments. As can be seen, initial lactose concentrations up to $200 \mathrm{~kg} \mathrm{~m}^{-3}$ favored the bioconversion to ethanol, but higher lactose concentration values drastically affected all the fermentative parameters. Cell growth was slightly increased by increasing the lactose concentration between 150 and $200 \mathrm{~kg} \mathrm{~m}^{-3}$ (Fig. 2A). In this same range of values, the substrate

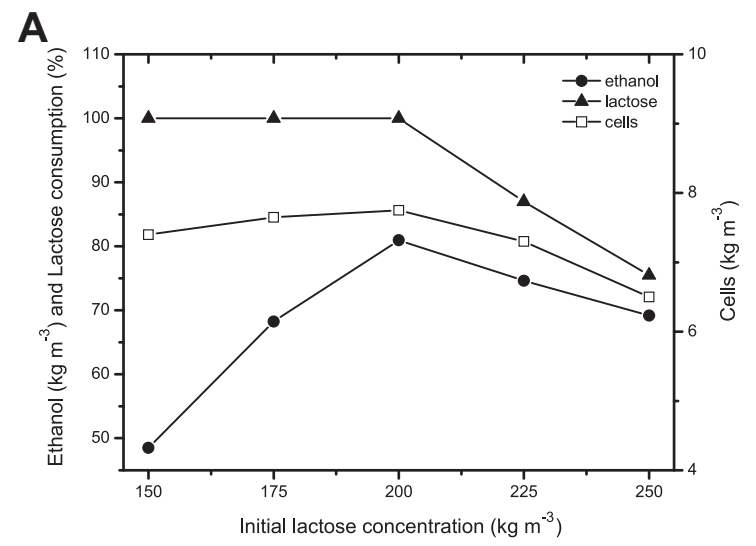

B

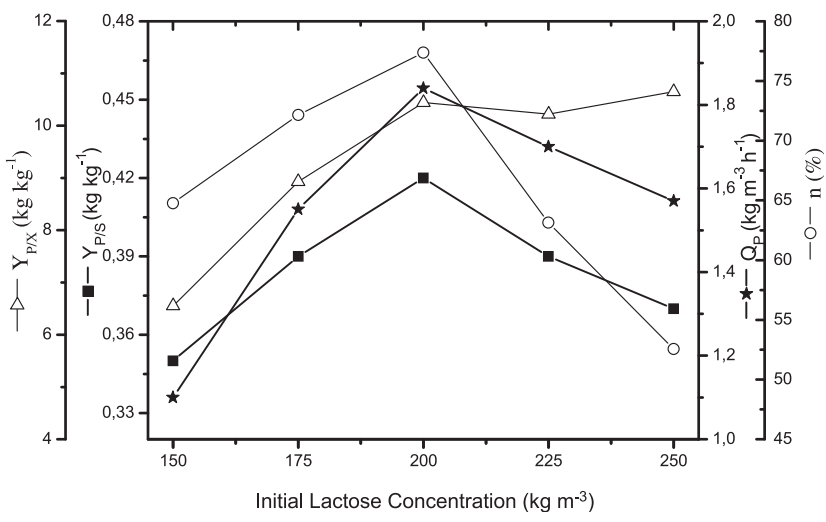

Fig. 2 - Effect of the initial lactose concentration on (A) cell growth, lactose consumption, ethanol production, and (B) in the fermentative parameters for ethanol production by $K$. fragilis in cheese whey powder solution. Fermentation temperature: $35{ }^{\circ} \mathrm{C}$; inoculum concentration: $1 \mathrm{~kg} \mathrm{~m}^{-3}$. 
consumption by the microorganism was not affected, and the ethanol production increased with the initial lactose concentration increase, achieving a maximum value of $80.95 \mathrm{~kg} \mathrm{~m}^{-3}$ (77.4\% of the theoretical value) when a deproteinized CWP solution containing $200 \mathrm{~kg} \mathrm{~m}^{-3}$ lactose was fermented. Lactose concentration values higher than $200 \mathrm{~kg} \mathrm{~m}^{-3}$ affected the ethanol production by the yeast, as can be seen in the profiles given in Fig. 2A and B. The observed ethanol concentration reduction by elevated initial sugar concentration is probably related with a substrate inhibition, which might have inactivated the cells due to high osmotic pressure encountered at high sugar content, causing high maintenance requirements [8].

The results here attained can be favorably compared with others reported in the literature. For example, fermentation of whey by K. marxianus MTCC 1288 under different initial lactose concentrations yielded maximum ethanol production (3.98 $\mathrm{kg} \mathrm{m}^{-3}$ ) when using $50 \mathrm{~kg} \mathrm{~m}^{-3}$ lactose. Higher lactose concentrations led to a drastic decrease in product formation and substrate utilization [15]. Lactose concentrations higher than $100 \mathrm{~kg} \mathrm{~m}^{-3}$ had an inhibitory effect on the specific growth rate, lactose utilization rate, and ethanol production rate by Candida pseudotropicalis [16]. Ethanol bioconversion by a recombinant Saccharomyces cerevisiae was also affected by initial lactose concentrations higher than $100 \mathrm{~kg} \mathrm{~m}^{-3}$. The highest value $(59 \%)$ decreased to $53 \%$ when using initial lactose concentrations higher than $100 \mathrm{~kg} \mathrm{~m}^{-3}$ [17]. Ethanol production by $K$. fragilis (present work) was only affected by lactose concentrations higher than $200 \mathrm{~kg} \mathrm{~m}^{-3}$. This finding represents an advantage because the costs of the process can be significantly reduced with the lactose concentration increase [2].

\section{Conclusions}

The initial lactose concentration in deproteinized cheese whey powder solution exerted great influence on ethanol production by $\mathrm{K}$. fragilis, being the maximum product formation $\left(80.95 \mathrm{~kg} \mathrm{~m}^{-3}\right.$ ) obtained when using an initial lactose concentration of $200 \mathrm{~kg} \mathrm{~m}^{-3}$. This value is about 4 times higher than that achieved during the fermentation of non-concentrated cheese whey, and represents thus an interesting alternative to decrease the distillation costs for ethanol production from cheese whey.

\section{Acknowledgments}

The authors acknowledge the financial support from "CAPES/ Grices (BEX2150/07-7) and Lactogal for supplying cheese whey powder.

\section{R E F E R E N C E S}

[1] Ghaly AE, El-Taweel AA. Kinetic modelling of continuous production of ethanol from cheese whey. Biomass Bioenerg 1997;6:461-72.

[2] González Siso MI. The biotechnological utilization of cheese whey: a review. Bioresour Technol 1996;57:1-11.

[3] Panesar PS, Kennedy JF, Gandhi DN, Bunko K. Bioutilisation of whey for lactic acid production. Food Chem 2007;105:1-14.

[4] Dragone G, Mussatto SI, Oliveira JM, Teixeira JA. Characterisation of volatile compounds in an alcoholic beverage produced by whey fermentation. Food Chem 2009; 112:929-35.

[5] Kim S, Dale BE. Global potential bioethanol production from wasted crops and crop residues. Biomass Bioenerg 2004;26: 361-75.

[6] Staniszewski M, Kujawski W, Lewandowska M. Semicontinuous ethanol production in bioreactor from whey with co-immobilized enzyme and yeast cells followed by pervaporative recovery of product - Kinetic model predictions considering glucose repression. J Food Eng 2009; 91:240-9.

[7] Guadix A, Sorenson E, Papageorgiou LG, Guadix EM. Optimal design and operation of ultrafiltration plants. J Membr Sci 2004;235:131-8.

[8] Ozmihci S, Kargi F. Fermentation of cheese whey powder solution to ethanol in a packed-column bioreactor: effects of feed sugar concentration. J Chem Technol Biotechnol 2009; 84:106-11.

[9] Kargi F, Ozmihci S. Utilization of cheese whey powder (CWP) for ethanol fermentations: effects of operating parameters. Enzym Microb Technol 2006;38:711-8.

[10] Ozmihci S, Kargi F. Continuous ethanol fermentation of cheese whey powder solution: effects of hydraulic residence time. Bioproc Biosyst Eng 2007;30:79-86.

[11] Mawson AJ. Bioconversions for whey utilization and waste abatement. Bioresour Technol 1994;47:195-203.

[12] Tango MSA, Ghaly AE. Effect of temperature on lactic acid production from cheese whey using Lactobacillus helveticus under batch conditions. Biomass Bioenerg 1999;16:61-78.

[13] Ozmihci S, Kargi F. Kinetics of batch ethanol fermentation of cheese-whey powder (CWP) solution as function of substrate and yeast concentrations. Bioresour Technol 2007;98: 2978-84.

[14] Zafar S, Owais M. Ethanol production from crude whey by Kluyveromyces marxianus. Biochem Eng J 2006;27:295-8.

[15] Zafar S, Owais M, Saleemuddin M, Husain S. Batch kinetics and modelling of ethanolic fermentation of whey. Int J Food Sci Tech 2005;40:597-604.

[16] Ghaly AE, El-Taweel AA. Effect of lactose concentration on batch production of ethanol from cheese whey using Candida pseudotropicalis. Trans ASAE 1995;38:1113-20.

[17] Guimarães P, Klein J, Domingues L, Teixeira JA. Fermentation performance of a recombinant lactose-consuming flocculating Saccharomyces cerevisiae strain. Braz J Food Technol 2005;3:34-9. 